\title{
In-vitro $\alpha$-Glucosidase Inhibitory Activity of Litsea petiolata Hk. f
}

\author{
Neneng Siti Silfi Ambarwati ${ }^{1}$, Berna Elya ${ }^{2 *}$, Putu Gita Maya Widyaswari Mahayasih ${ }^{3}$, \\ Muhamad Sharul Nizam Awang ${ }^{4}$, Hanita Omar ${ }^{4}$, Islamudin Ahmad ${ }^{5}$, Dwi Atmanto ${ }^{1}$ \\ \{neneng_ambarwati@yahoo.co.id ${ }^{1}$, berna.elya@gmail.com², aya.mahayasih@gmail.com ${ }^{3}$, \\ 17202353@siswa.um.edu.my ${ }^{4}$, hanita74@um.edu.my , islamudinahmad@yahoo.com6 $^{6}$, \\ dwiatmanto64@gmail.com ${ }^{7}$ \} \\ *corresponding author
}

Department of Cosmetology, Faculty of Engineering, Universitas Negeri Jakarta, Jl. Rawamangun Muka, Jakarta Timur, DKI Jakarta, 13220, Indonesia ${ }^{1,7}$, Department of Pharmaceutical Biology, Faculty of Pharmacy, Universitas Indonesia, Depok, 16424, West Java, Indonesia ${ }^{2}$, Department of Pharmacy,

Faculty of Health and Sciences, Universitas Esa Unggul, Jakarta, Indonesia ${ }^{3}$, Chemistry Division, Centre for Foundation Studies in Science, University of Malaya, Kuala Lumpur, 50603, Malaysia ${ }^{4,5}$,

Department of Pharmaceutical Sciences, Faculty of Pharmacy, Universitas Mulawarman, Samarinda, East Kalimantan, Indonesia ${ }^{6}$

\begin{abstract}
Alpha-glucosidase is an enzyme that plays a role in the process of hydrolysis of carbohydrates into glucose so that the enzyme inhibitor can inhibit the process of glucose absorption. One synthetic drug that has a mechanism of action to inhibit the activity of the alpha-glucosidase enzyme is acarbose, however in the long term has side effects, such as digestive system disorders. Therefore, the use of natural medicines as alternative therapies can be considered for use. This study aimed to determine the inhibitory activity of the enzyme alpha-glucosidase from extracts and fractions of Litsea petiolata Hk. f bark. The extraction method used maceration, and fractionation using column chromatography. The results showed that the $\mathrm{IC}_{50}$ values for extract, fraction $\mathrm{B}$, fraction $\mathrm{D}$, and acarbose were $444.17 \mu \mathrm{g} / \mathrm{ml}, 682.85 \mu \mathrm{g} / \mathrm{ml}, 1683.45 \mu \mathrm{g} / \mathrm{ml}$, and $110.60 \mu \mathrm{g} / \mathrm{ml}$, respectively. In conclusion, the activity extract as the alpha-glucosidase was higher than the fractions but lower than acarbose.
\end{abstract}

Keywords: Litsea petiolata Hk. F, extract, fraction, alpha-glucosidase inhibitory

\section{Introduction}

Litsa petiolata $\mathrm{Hk}$. f belongs to Family Lauraceae, this plant commonly found in Hutan Simpan Rimba Teloi, Sik, Kedah, Malaysia [1]. L. petiolata is native to southern Thailand wahich is also called "Thummong" and commonly used to give flavor to food dishes, because containing 7 aldehydes, 5 ketones, and 3 esters [2]. Some natural compounds that have been successfully isolated on the stem of this plant such as arbine, norharman reticuline, isboldine, and thalifoline [1]. In the leaves, there is leaf oil which has been widely studied as an antibacterial [3].

The enzyme of $\alpha$-glucosidase catalyzes the final step in the process of digestion of carbohydrates [4]. Inhibition of action of $\alpha$-glucosidase can inhibit the liberation of d-glucose from complex carbohydrates so that absorption is delayed [4]. This will cause a decrease in 
plasma glucose levels [4]. In this study, an in vitro $\alpha$-glucosidase inhibitory activity test was carried out from Litsea petiolata Hk. f bark.

The ability to reduce glucose levels in blood plasma by extract of plant can add information on the precense of herbal medicines for type-2 diabetes [5]. Diabetes is a disease that continues to grow and is a heavy economic burden for both patients and countries. This chronic metabolic disease can also cause complications that endanger the patient [5].

Diabetes mellitus is a systemic metabolic disease characterized by hypoinsulinemia, hyperlipidemia, hyperglycemia, and hyperaminoacidemia which causes the secretion and the act of insulin decrese [6]. Diabetes mellitus therapy is available in the form of insulin and oral antidiabetic, such as biguanide, sulfonylureas, $\alpha$-glucosidase enzyme inhibitors, and glinides [6]. This study aimed to examine the extract and fraction of L. petiolata as an inhibitor of the $\alpha$ glucosidase enzyme which is one of the methods of diabetes mellitus therapy. Acarbose is a diabetic drug with a mechanism to inhibit the $\alpha$-glucosidase enzyme. So in this study, acarbose was used as a control [7].

\section{Method}

Plant Material: The stem of L. petiolata was obtained from Sirnpan Rimba Teloi forest, Sik, Kedah, Malaysia in February 2017 [1]. The firstly, a fat was removed from dried powder sample by soaking it using n-hexane for 3 days with moistened by $\mathrm{NH}_{4} \mathrm{OH}$. The sample was then extracted using a soxhletation method with dichloromethane for 18 hours. Fractionation of the extract was carried out using column chromatography withincreasing polarity solvent (dichlormethane and methanol) [1].

$\alpha$-Glucosidase inhibitory assay: The assay was performed using microplate reader (Versamax ELISA, USA) according to previously study by Mahayasih et al [8]. To obtain 50\% inhibition concentration $\left(\mathrm{IC}_{50}\right), 30 \mu \mathrm{l}$ samples with various concentrations were put in 96 microplate wells, then was added by $36 \mu 1$ of phosphate buffer $\mathrm{pH} 6.8$ and, as the substrate, 17 $\mu 1$ of $4 \mathrm{mM}$ p-NPG (p-nitrofenil- $\alpha$-D-glucopiranoside) (Sigma-Aldrich, Switzerland) [8]. The microplate was inserted into a microplate reader, shaked and incubated at $37^{\circ} \mathrm{C}$ for 5 minutes, then was added $17 \mu 1$ of enzyme $\alpha$-glucosidase (Saccharomyces cerevisiae, Sigma-AldrichGermany) at concentration 0.8 unit/L [8]. Subsequently re-incubated at $30^{\circ} \mathrm{C}$ for 15 minutes, the reaction was then terminated by adding $100 \mu \mathrm{l}$ of $267 \mathrm{mM}$ Sodium carbonate solution [8]. The absorbance of the solution was measured with a microplate reader at $400 \mathrm{~nm}$. Each test was repeated three times. A solution system contains substrate and enzyme, without extract was used as a blank and a solution system without enzyme was used as a control. Acarbose was used as a positive control. The percent inhibition of the enzyme by samples was calculated by following formula [8]:

Inhibition $(\%)=[($ blank absorption - sample absorption $) /$ blank absorption $]$ x 100 .

The $\mathrm{IC}_{50}$ value showed the concentration of extract or fraction required for inhibiting $50 \%$ of $\alpha$ glucosidase enzyme activity. 


\section{Result}

The result of $\alpha$-glucosidase inhibitory activity assay of extract and fraction of L. petiolata and also acarbose (positive control) can be seen in Figure 1-4,

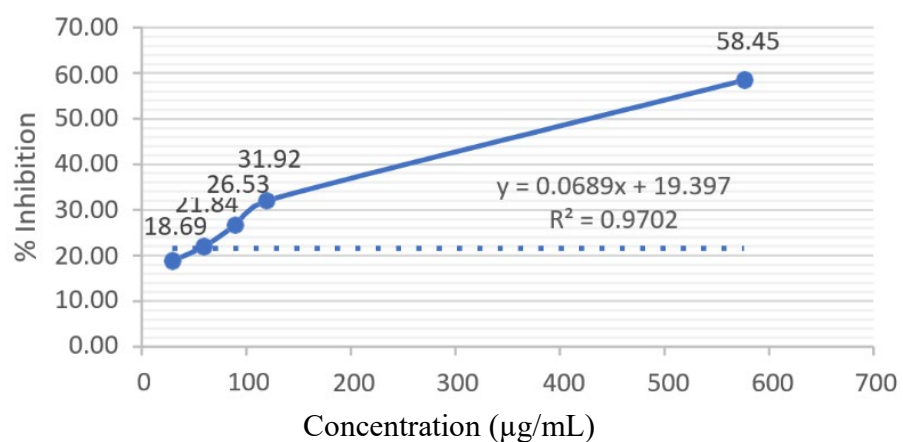

Fig. 1. Average results of the enzyme $\alpha$-glucosidase inhibition percentage of $L$. petiolata stem extract

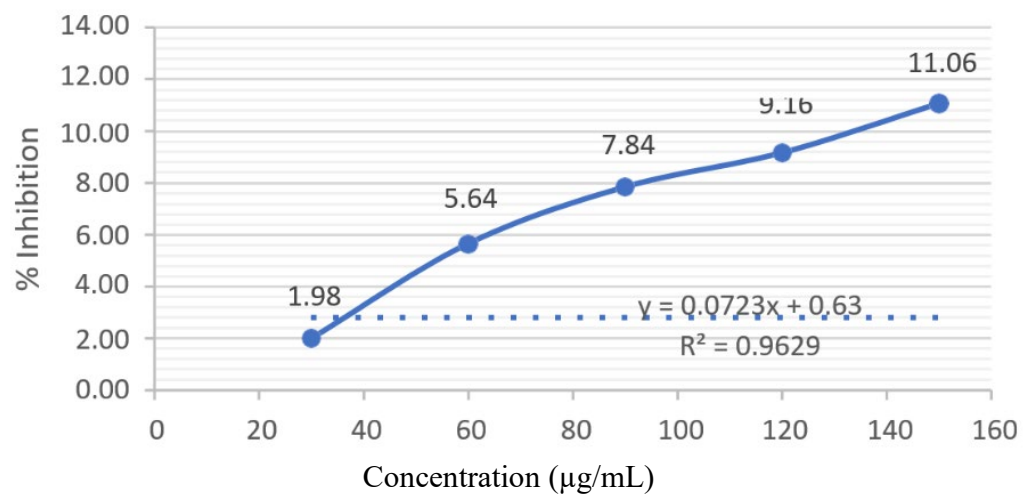

Fig. 2. Average results of the enzyme $\alpha$-glucosidase inhibition percentage of $L$. petiolata stem fraction B

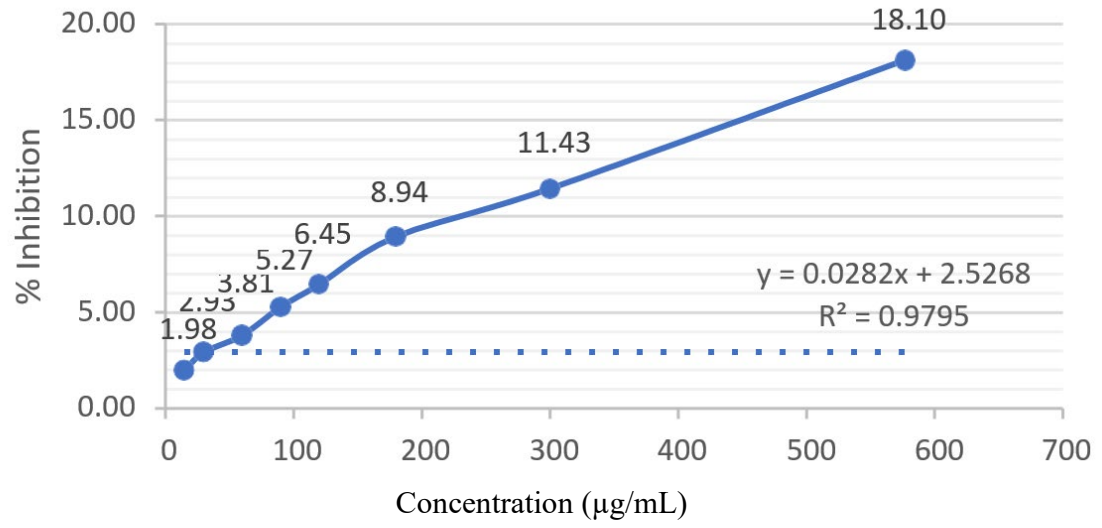

Fig. 3. Average results of the enzyme $\alpha$-glucosidase inhibition percentage of $L$. petiolata stem fraction D 


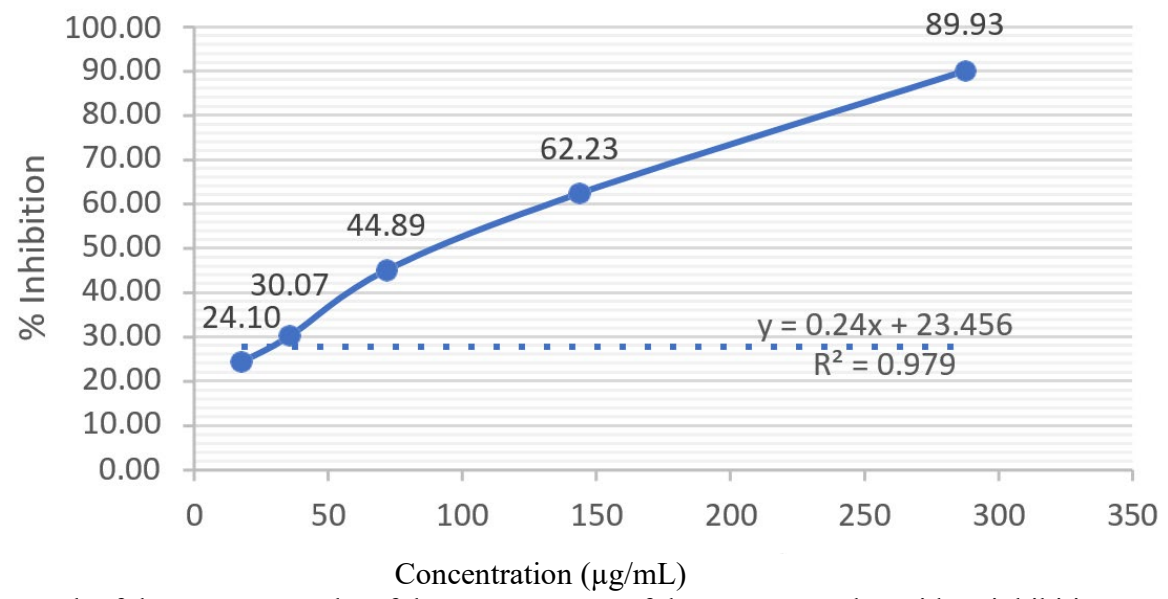

Fig. 4. Graph of the average results of the measurement of the enzyme $\alpha$-glucosidase inhibition percentage of acarbose (positive control) with five concentrations

According to the results of the $\alpha$-glucosidase inhibitory activity the dichloromethane extract has an $\mathrm{IC}_{50}$ value of almost four times that of $\mathrm{IC}_{50}$ of acarbose and its fractions are even greater. $\mathrm{IC}_{50}$ calculation results can be seen in Table 1.

Table 1. The result of $\mathrm{IC}_{50}$ calculation of $\alpha$-glucosidase inhibitory activity

\begin{tabular}{lc}
\hline \multicolumn{1}{c}{ Samples } & IC50 $(\boldsymbol{\mu g} / \mathbf{m L})$ \\
\hline The Litsea petiolata Hk. f bark & 444.17 \\
dichloromethane extract & \\
The fraction B of the extract & 682.85 \\
The fraction D of the extract & 1683.45 \\
Acarbose & 110.6 \\
\hline
\end{tabular}

\section{Discussion}

An $\alpha$-glucosidase is one of the enzymes in addition to the amylase enzyme that plays an important role in the process of carbohydrate hydrolysis so that the activity of the $\alpha$-glucosidase can inhibit the digestion of carbohydrates to reduce the speed of glucose uptake into the blood [9]. The $\alpha$-glucosidase enzyme inhibiting agent can be used as a therapeutic approach to control hyperglycemia [9]. High blood glucose levels are a sign of chronic metabolic disorders, namely diabetes mellitus [4]. Treatment of diabetes mellitus can be done by controlling high blood glucose levels [10]. The action of $\alpha$-glucosidase inhibitors can block the activity of glucosidase thereby slowing the digestion process and absorption of carbohydrates. This causes the level of glucose in the blood to decrease [10].

Some $\alpha$-glucosidase inhibitors, such as acarbose and voglibose, which are obtained from natural sources, can clinically treat diabetes mellitus [10]. Acarbose is one of the drugs commonly used to inhibit glucose absorption, only it has side effects such as liver toxicity and undesirable effects on gastrointestinal [9]. Therefore, it is necessary to find alternative treatments with natural ingredients that can inhibit the activity of the $\alpha$-glucosidase enzyme without causing side effects [10]. This study tested the inhibitory activity of the enzyme $\alpha$ - 
glucosidase from the L. petiolata bark to determine the effectiveness of the extract and its fractions.

The activity of $\alpha$-Glucosidase inhibitors was demonstrated by Genus Litsea (Lauraceae) that is oleum of L. coreana, where it was collected from Ningguo, Mingshan, dan Wuxi, Cina with $\mathrm{IC}_{50}$ value $1.71,2.64$, and $3.88 \mathrm{mg} / \mathrm{mL}$, respectively [11]. The $\mathrm{IC}_{50}$ of dichloromethane extract of $L$ petiolata stem from Kedah Malaysia is still lower than $L$. coreana leaf oil from China. L. coreana var. Lanuginosa leaf, which is commonly consumed as a tonic in China, has been distilled using water to obtain essential oils and 50 compounds have been identified by Gas Chromatography-Mass Spectrometer which are citral, caryophyllene, dodecanal, $\alpha$ humulene, and decanal [12]. While, some alkaloids have been isolated from L. petiolata bark dicloromethane extracts, namely arbine, norharman, reticuline, isoboldine, dan thalifoline [1].

In addition, L. lancifolia originating from Uttarakhand, India has also been studied, reported to have potential as an antidiabetic drug with IC50 values inhibiting the $\alpha$-glucosidase $229.61 \mu \mathrm{g} / \mathrm{mL}$, with $\mathrm{IC}_{50}$ acarbose values (positive control) $50.26 \pm 9.57 \mu \mathrm{g} / \mathrm{mL}$ [13]. Epigallocatechin gallate from L. coreana has also been investigated for its inhibition of the $\alpha$ glucosidase enzyme with an $\mathrm{IC}_{50}$ value of $3.8 \mathrm{mg} / \mathrm{mL}$ [14].

\section{Conclusion}

Antidiabetic activity of dichloromethane extracts of L. petiolata bark and both fractions have been investigated through the $\alpha$-glucosidase inhibition assay using a microplate reader spectrophotometric method and acarbose as a positive control. The results showed the potential of $L$. petiolata bark dichloromethane extract to be further developed as an antidiabetic, with better results than its fractions.

\section{Acknowledgements}

The authors acknowledge to gratitude The Directorate of Research and Community Service, Ministry of Research, Technology and Higher Education of the Republic of Indonesia, which has funded this research on a primary research grant in 2020 with the assignment agreement number: 26 / SP2H / DRPM / LPPM / III / 2020.

\section{References}

[1] H. Omar, M. A. Nafiah, M. R. Mukhtar, K. Awang, and A. H. A. Hadi, "Harman and isoquinoline alkaloids from Litsea petiolata Hk. f (Lauraceae),” Malaysian J. Sci., vol. 29, no. 3, pp. 268-279, 2010 .

[2] P. Thongthip, P. Atiphasaworn, S. Monggoot, A. Pansanit, and P. Pripdeevech, "In vitro antibacterial activity and essential oil composition of Litsea petiolata Hook. f. leaves," J. Appl. Pharm. Sci., vol. 7, no. 9, pp. 94-98, 2017, doi: 10.7324/JAPS.2017.70913.

[3] K. Mahattanatawee, T. Luanphaisarnnont, and R. Rouseff, "Comparison of Aroma Character Impact Volatiles of Thummong Leaves (Litsea petiolata Hook. f.), Mangdana Water Beetle (Lethocerus indicus), and a Commercial Product as Flavoring Agents in Thai Traditional Cooking," J. Agric. Food Chem., vol. 66, no. 10, pp. 2480-2484, 2018, doi: 10.1021/acs.jafc.7b01499.

[4] S. Kumar, S. Narwal, V. Kumar, and O. Prakash, " $\alpha$-glucosidase inhibitors from plants: A natural approach to treat diabetes," Pharmacogn. Rev., vol. 5, no. 9, pp. 19-29, 2011, doi: 10.4103/09737847.79096.

[5] C. L. T. Chang, Y. Lin, A. P. Bartolome, Y. C. Chen, S. C. Chiu, and W. C. Yang, "Herbal therapies 
for type 2 diabetes mellitus: Chemistry, biology, and potential application of selected plants and compounds," Evidence-based Complement. Altern. Med., vol. 2013, pp. 1-33, 2013, doi: $10.1155 / 2013 / 378657$.

[6] C. Dwivedi and S. Daspaul, "Antidiabetic Herbal Drugs and Polyherbal Formulation Used For Diabetes: A Review," J. Phytopharm. JPHYTO, vol. 2, no. 23, pp. 44-51, 2013.

[7] S. Adisakwattana, O. Lerdsuwankij, U. Poputtachai, A. Minipun, and C. Suparpprom, "Inhibitory Activity of Cinnamon Bark Species and their Combination Effect with Acarbose against Intestinal $\alpha$-glucosidase and Pancreatic $\alpha$-amylase," Plant Foods Hum. Nutr., vol. 66, no. 2, pp. 143-148, 2011, doi: 10.1007/s11130-011-0226-4.

[8] P. G. M. W. Mahayasih, B. Elya, and M. Hanafi, "Alpha-glucosidase inhibitory activity of Garcinia lateriflora Blume Leaves," J. Appl. Pharm. Sci., vol. 7, no. 10, pp. 100-104, 2017, doi: 10.7324/JAPS.2017.71014.

[9] X. Wu, M. Hu, X. Hu, H. Ding, D. Gong, and G. Zhang, "Inhibitory mechanism of epicatechin gallate on $\alpha$-amylase and $\alpha$-glucosidase and its combinational effect with acarbose or epigallocatechin gallate," J. Mol. Liq., vol. 290, no. 111202, pp. 1-10, 2019, doi: 10.1016/j.molliq.2019.111202.

[10] Z. Yin, W. Zhang, F. Feng, Y. Zhang, and W. Kang, " $\alpha$-Glucosidase inhibitors isolated from medicinal plants," Food Sci. Hum. Wellness, vol. 3, no. 3-4, pp. 136-174, 2014, doi: 10.1016/j.fshw.2014.11.003.

[11] M. A. M. Azhar and W. M. N. H. W. Salleh, "Chemical composition and biological activities of essential oils of the genus litsea (Lauraceae) - A review," Agric. Conspec. Sci., vol. 85, no. 2, pp. 97-103, 2020.

[12] Z. Qin et al., "Comparative study on the essential oils of six Hawk tea (Litsea coreana Levl. var. lanuginosa) from China: Yields, chemical compositions and biological activities," Ind. Crops Prod., vol. 124, no. May, pp. 126-135, 2018, doi: 10.1016/j.indcrop.2018.07.035.

[13] M. Alsawalha et al., "Effect of Litsea lancifolia leaf extract on glucose transporter 4 translocation and glucose uptake in 3T3L1 cell line," J. Pharm. Bioallied Sci., vol. 11, no. 3, pp. 240-247, 2019, doi: 10.4103/jpbs.JPBS_53_19.

[14] X. Jia, P. Li, J. Wan, and C. He, "A review on phytochemical and pharmacological properties of Litsea coreana," Pharm. Biol., vol. 55, no. 1, pp. 1368-1374, 2017, doi: 10.1080/13880209.2017.1302482. 